\title{
CMOSゲート回路を断線センサとして用いた部品接合不良検出法
}

\author{
小野 安季良 ${ }^{*}$, 一宮 正博**, 四柳 浩之**, 高木 正夫***, 橋爪 正樹**
}

\section{Open Lead Detection Method by Sensing the Switching Current of CMOS Gate on Sensing Probe}

\author{
Akira ONO*, Masahiro ICHIMIYA** , Hiroyuki YOTSUYANAGI** , Masao TAKAGI*** and Masaki HASHIZUME**
}

*詫間電波工業高等専門学校情報通信工学科（广 769-1192＼cjkstart香川県三豊市詫間町香田551）

**徳島大学大学院ソシオテクノサイエンス研究部（† 770-8506 徳島県徳島市南常三島町 2-1）

***詫間電波工業高等専門学校電子工学科（下 769-1192 香川県三豊市詫間町香田551)

*Department of Telecommunications, Takuma National College of Technology (551 Kouda, Takumacho, Mitoyo-shi, Kagawa 769-1192)

** Institute of Technology and Science, The University of Tokushima (2-1 Minamijosanjimacho, Tokushima-shi, Tokushima 770-8506)

*** Department of Electronic Engineering, Takuma National College of Technology (551 Kouda, Takumacho, Mitoyo-shi, Kagawa 769-1192)

\begin{abstract}
概要＼cjkstart本論文でははんだ付け時に発生するICのリードとプリント配線板のランド間の断線故障を検出する電気的検查法を 提案している。その検查法はオープンセンサとしてCMOSゲートICを使用し，検査プローブを検查対象リードに接触させ交流 電圧信号を印加したときのセンサの電源電流測定により，断線故障を検出するものである。本論文では, SSIおよびLSIのリー ドの断線故障検出がその検查法で行えることを実験で明らかにしている。また，その実験でその検出を可能にする交流電圧信 号の振幅之周波数を調查し, 電源電圧の 0.6 倍の振幅の交流電圧信号の印加により $1 \mu \mathrm{sec}$ の時間でリードの断線検出が行える ことも明らかにしている。
\end{abstract}

\begin{abstract}
We propose a new test method for detecting open leads on ICs. The test method is based on using the supply current of a CMOS gate as an open lead detector; the current flows when an AC voltage signal is provided to a targeted lead with a probe as a stimulus. To evaluate the test method, we examined whether it could detect open leads in SSIs and LSIs. The experimental results confirm that open leads can be detected within $1 \mu$ sec by providing an AC voltage signal with an amplitude that is $60 \%$ of the power supply voltage of the targeted IC.
\end{abstract}

Key Words: Open Lead, Electrical Test, Supply Current Test, CMOS IC

\section{1. 緒 言}

近年，可搬型電子機器にみられるように電子回路は高機 能性が求められる一方で, 小型・軽量化が求められ, 狭配 線のプリント配線板と狭ピッチ ICを用いて回路が実装され るようになってきた。それに伴い，回路実装時にはんだ不 良によるリードとプリント配線板上のランド間の断線故障 が発生しやすくなってきている。本論文ではその断線故障 を「リード浮き」と呼び，その検出を試みる。

そのはんだ付け時に発生する断線故障は非常に大きな抵 抗值の抵抗で断線する完全断線と, ある抵抗值を伴って断 線する抵抗断線に分類できる。はんだ付け時に発生する リード浮きは完全断線である場合が多いので本論文では完 全断線となるリード浮きを検出対象とする。

現在までにリード浮きを検出するためのさまざまな検査 法が提案されている。それらはIEEE1149.11)に代表される 論理值測定による検査法, 目視検査を自動化する外観検査 法 ${ }^{2), 3)}$ と電気的検査法に分類できる。
リード浮きは論理值に現れる故障の影響がさまざまな要 因で変化する可能性がある。そのため, 検査工程で必ず行 われる論理值測定による検査だけでは見逃す可能性があり, それ以外の検査法での検査が一般に行われている。

外観検査法ははんだの形状異常により検査する方法で, その判定精度を上げるために高度な画像処理手法を適用し

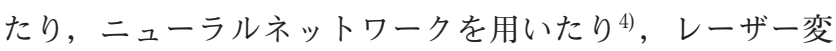
位計を用いて形状を測定したり ${ }^{5)}$ ，種々の検査法が提案 されている。その検査法では電気的な接続は調べないため, 外見上は正常にはんだ付けされているように見えても電気 的に断線している不良は発見できない。はんだ付け異常と 判定できる場合でも電気的には正常につながっている場合 がある。その場合には誤った判定結果を出し検査時間の増 大とそれに伴う検査コストの増大を招く。それに対し，電 気的検査法では電気的に導通を調べるため, そのような場 合でも誤判定しないという特長がある。

電気的検査法としてはリードとランド間の静電容量や抵 抗值を測定する方法, 検査時にのみ IC 内の寄生ダイオード 
に電流を流しその電流異常で検查する方法や $\mathrm{EO}$ 効果（電 気光学効果) を利用する方法 ${ }^{6)}$, 回路外部から交流磁界を 印加しそれによる誘導電流の異常により検查する方法があ る。それ以外に磁界分布異常で検查する方法 ${ }^{7}$, 電磁波の 相互変調ひずみで検查する方法 ${ }^{8}$ が提案されている。しか しそれらの検査法では微小な異常を検出し検査するため, 確実にリード浮きを発見することが難しい。

より確実にリード浮き検出を可能にするため，われわれ は過去にリード浮き検出を可能とする回路の電源電流測定 による検查法を提案した 9,10)。文献9)の検查法では検查対 象回路に検查入力之交流電界を印加し, 回路の電源電流に 異常を発生させ, リード浮きを検出する。この検査法は非 接触でリード浮きを発見できるという特長をむつが，検査 時にIC 外部から交流電界を印加するために IC 外部に設け た電極間に $100 \mathrm{~V}$ 程度の振幅の交流電圧信号を印加しなけ ればならない場合がある ${ }^{11)}$ 。実用的にはできる限り小さな 振幅の交流電圧印加での検查が望ましいので, 文献 10)で は検查対象リードに検査プローブを接触させ, IC の電源電 圧以下の振幅の交流電圧信号を直接印加し, 検查回路の電 源電流に現れる異常によりリード浮きを検出する検査法と その検查回路を提案した。

しかし，その検查回路を用いて検查すると，負電圧印加 時に検查対象 ICを壊す可能性がある。そこでわれわれはそ の破壊が生じないようにその検查回路を改良した。また， その検查回路を用いてリード浮き検出を可能にする交流電 圧信号の振幅とその周波数を調查した。本論文では改良し た検査回路とそれを用いた検査法, ならびに印加する交流 信号に関する調查結果について述べる。

\section{2. リード浮き検出法}

Fig. 1 にCMOSインバータゲートの入出力特性を示す。 Fig. 1 (b)に示すように，ゲートの入力に $V_{\mathrm{DD}}$ むくは $0 \mathrm{~V} を$ 印加したとき, ゲートに電源電流は流れない。しかし, ゲートの入力電圧 $V_{\mathrm{i}}$ が式(1)の範囲内のとき, そのゲート 内部の $\mathrm{pMOS}$ と nMOS 両方が $\mathrm{ON}$ となり, 電源電流 $I_{\mathrm{DD}}$ が流 れる。

$$
V_{\mathrm{i} 1} \leq V_{\mathrm{i}} \leq V_{\mathrm{i} 2}
$$

文献 10)で提案したリード浮き検出法は, このCMOSイン バータゲートの電気的特性を利用したものである。本論文 でもこの特性を利用し, 論理信号の入力用リードと出力用 リードのリード浮きを本検查法の検出対象故障とし, その 検出を行う。

Fig. 2 に本論文で提案する検查法のための検查回路を示 す。Fig. 2 に示すようにその検查回路は交流電圧源, 抵抗 $R_{\mathrm{T}}, \mathrm{CMOS}$ インバータゲート INV, ダイオード $D_{1}$ と検査プ ローブから構成する。検查時には交流電圧源から式(2)の交 流電圧 $v_{\mathrm{T}}$ を発生させ, 検查プローブを論理信号入力用リー

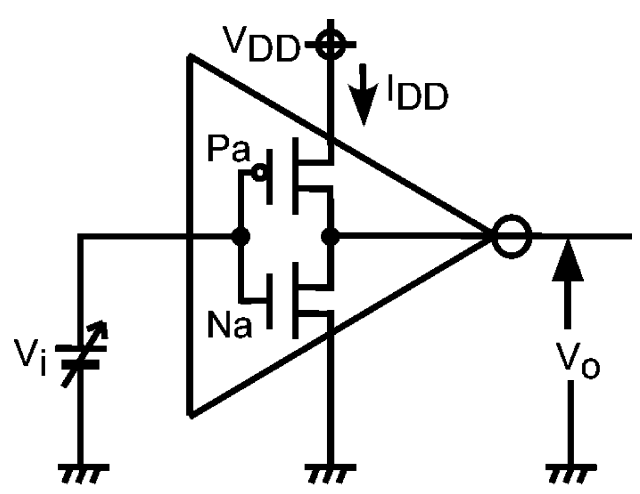

(a)Measurement Circuit

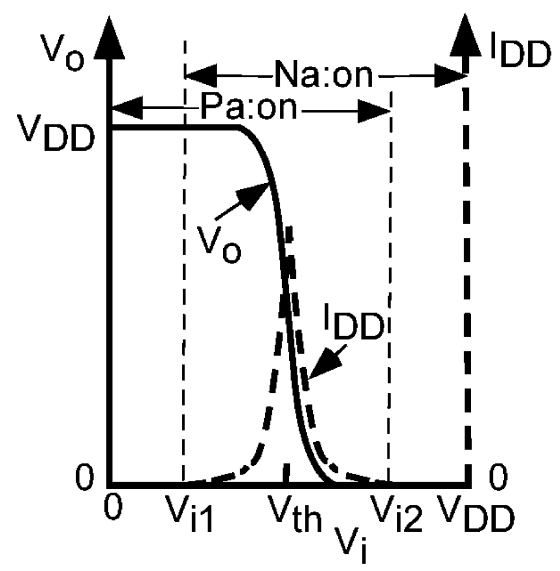

(b) DC characteristics

Fig. 1 DC characteristics of CMOS inverter gate

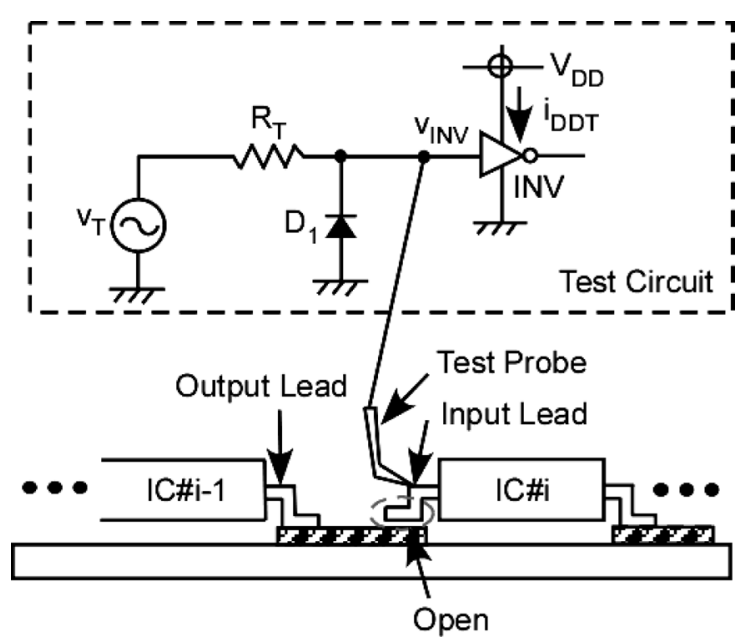

Fig. 2 Test circuit for open lead detection

ドに接触させ印加する。

$$
v_{\mathrm{T}}=V_{\mathrm{TS}} \cdot \sin \left(2 \pi \cdot f_{\mathrm{T}} \cdot \mathrm{t}\right)
$$

そのときの INV の電源電流 $i_{\mathrm{DDT}}$ を測定し, 測定值 $I_{\mathrm{DDT}}$ が式 (3)を満たせば検査プローブを接触したリードにリード浮き が発生していると判定する。

$$
I_{\mathrm{DDT}} \geqq I_{\mathrm{th}}
$$

ここで $I_{\mathrm{th}}$ は故障判定しきい值で, 正常回路検查時の $I_{\mathrm{DDT}}$ の 
ばらつきと $i_{\mathrm{DDT}}$ 測定分解能の大きい方の值を $I_{\mathrm{th}}$ として用い る。

式(2)の $V_{\mathrm{TS}}$ は検査対象 IC の電源電圧 $V_{\mathrm{DD}}$ 以下で，かつ $1 / f_{\mathrm{T}}$ の 1 周期内で Fig. 2 内の INV の入力電圧 $v_{\text {INV }}$ が Fig. 1(b) の $V_{\mathrm{i} 1}$ 以上となる電圧である。検查プローブを接触させた リードにリード浮きが発生していない正常時では， $v_{\mathrm{INV}}$ は IC\#i-1の出力論理レベルとなり, Fig. 1(b)の $V_{\mathrm{i} 1} \sim V_{\mathrm{i} 2}$ の範 囲内の值とならないため， $i_{\mathrm{DDT}}$ はほとんど流れない。それ に対し, リード浮き発生時には $v_{\mathrm{INV}}$ が $v_{\mathrm{T}}$ に従って変化する ため, $v_{\mathrm{INV}}$ が $V_{\mathrm{i} 1} \sim V_{\mathrm{i} 2}$ の範囲内の電圧となり, 正常時には流 れない大きな $i_{\mathrm{DDT}}$ が流れる。本検査法ではこの電流異常で リード浮きを検出する。

Fig. 2 の IC\#i にリード浮きが発生しそれを本検查法で検 查するときに現れる $i_{\mathrm{DDT}}$ 波形例を Fig. 3 に示す。Fig. 3 に示 すようにリード浮き発生時は $v_{\mathrm{INV}}$ は $v_{\mathrm{T}}$ に従って変化する。 しかし, 入出力保護ダイオードがICに内蔵されているた め，そのダイオードの順方向電圧降下を $V_{\mathrm{d}}$ とすると Fig. 3 に示すように $v_{\mathrm{INV}}$ はー $V_{\mathrm{d}}$ より小さくならない。

Fig. 3(a) は $v_{\mathrm{INV}}$ の最大值 $V_{\mathrm{INV} m a x}$ が Fig. 1(b) の $V_{\mathrm{i} 1} \sim V_{\mathrm{th}}$ の範 囲内となる $V_{\mathrm{TS}}$ の $v_{\mathrm{T}}$ を印加した場合の波形例である。 $v_{\mathrm{INV}}$ が $V_{\mathrm{i} 1}$ より大きくなると, Fig. 1 の特性より INV に正常時に は流れない過大な電流が $t_{\mathrm{AB}}$ の期間流れる。

Fig. 3(b) は $V_{\text {INVmax }}$ が Fig. 1(b)の $V_{\mathrm{i} 2}$ より大きくなる $V_{\mathrm{TS}}$ の $v_{\mathrm{T}}$ を印加した場合の波形例である。この場合, Fig. 3(b)の $t_{\mathrm{CD}}$ 間で $v_{\mathrm{INV}}$ が $V_{\mathrm{i} 1} \sim V_{\mathrm{th}}$ となり $i_{\mathrm{DDT}}$ が増大し, $t_{\mathrm{DE}}$ 間で $v_{\mathrm{INV}}$ が $V_{\mathrm{th}}$ より大きくなり $i_{\mathrm{DDT}}$ が減少し, $t_{\mathrm{EF}}$ 間で $v_{\mathrm{INV}}$ が $V_{\mathrm{i} 2}$ より大 きくなり $i_{\mathrm{DDT}}$ が流れなくなる。 $t_{\mathrm{FG}}$ 間で $v_{\mathrm{INV}}$ が $V_{\mathrm{th}}$ に向かっ て減少するので $i_{\mathrm{DDT}}$ が増大し, $t_{\mathrm{GH}}$ で $v_{\mathrm{INV}}$ が $V_{\mathrm{i} 1}$ に向かって 減少するので $i_{\mathrm{DDT}}$ が減少する。そのため過大な $i_{\mathrm{DDT}}$ が $v_{\mathrm{T}}$ の 1 周期中に 2 度現れる。 $V_{\mathrm{INVmax}}$ が Fig. $1(\mathrm{~b})$ の $V_{\mathrm{th}} \sim V_{\mathrm{i} 2}$ の場合 は $t_{\mathrm{EF}}$ が短くなるだけで Fig. 3(b) と同様な波形が得られる。

Fig. 3 より, 現れる電源電流波形が $V_{\mathrm{TS}}$ により異なるし, $I_{\mathrm{th}}$ 以上の $i_{\mathrm{DDT}}$ が流れる期間も異なることがわかる。いずれ の場合でもリード浮きが検查プローブを接触させたリード で発生すると $I_{\mathrm{th}}$ 以上の大きな電流が流れるので, 本検查法 では式(3)でリード浮きを検出する。

本検查法では検查プローブはプリント配線板の検查用ラ ンドに接触させるのでなく, IC の入力用リードに接触させ て検查する。検查対象の 1 つである論理信号を出力する IC の出力用リードのリード浮きは, そのリードがつながる次 段 IC の論理信号入力用リード浮きと等価な故障であるた め, 本検查法では次段 IC の入力リード検查時に検出する。 しかし, 回路からの外部出力信号を出力するICの出力用 リードの場合, 次段のICが存在しない。そのためその出力 リードのリード浮きはそのリードにつながるプリント配線 板からの外部出力端子に検查プローブを接触させ検查する。

文献 10) で提案した検査回路では $D_{1}$ は含まれていない。 そのため, 検查時に負の電圧が検查対象リードに印加され,
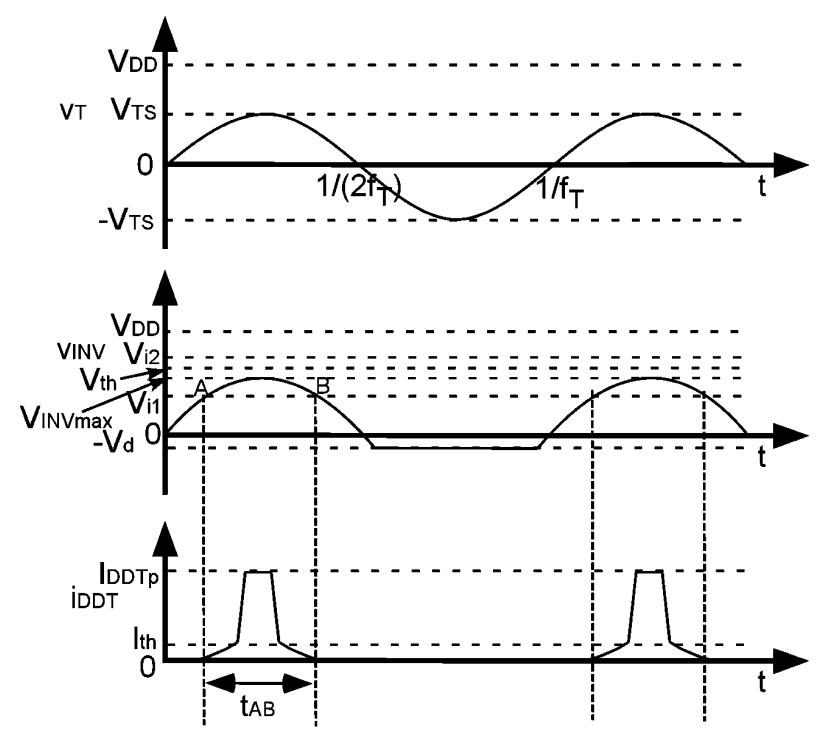

(a) $V_{\text {i1 }} \leq V_{\text {INVmax }} \leq V_{\text {th }}$

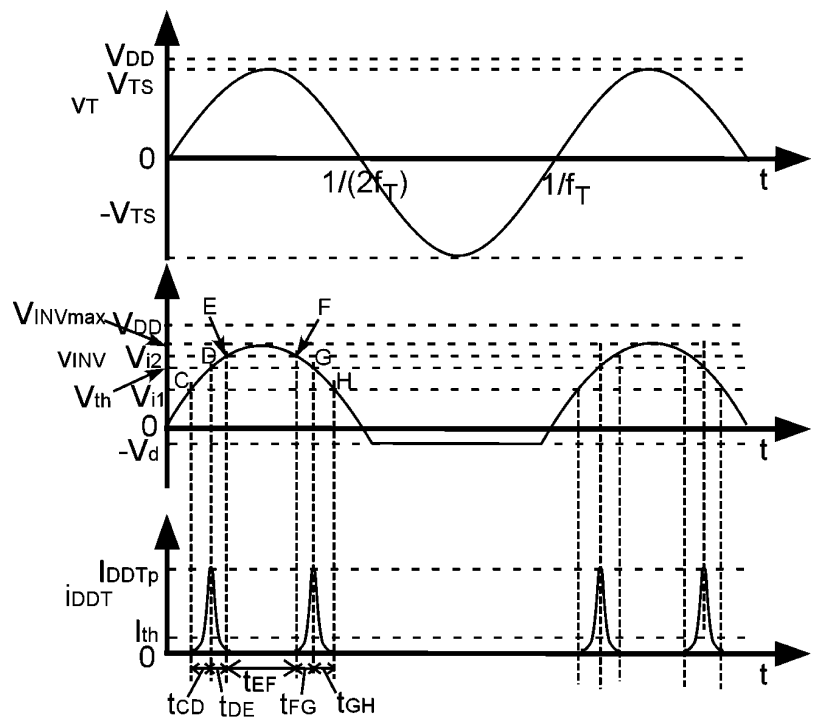

(b) $\mathrm{V}_{\mathrm{i} 2} \leq \mathrm{V}_{\text {INVmax }} \leq \mathrm{V}_{\mathrm{DD}}$

Fig. 3 Elevated $i_{\mathrm{DDT}}$ generation mechanism

検查対象 IC を破壊する可能性がある。一般に IC 内には入 出力保護ダイオードが各入出力リードと GND 端子間に内 蔵されているが，検查対象 IC の検查時の非破壊を保証する ため本検查回路では $D_{1}$ を含めている。

Fig. 2ではオープンセンサとしてインバータゲートを使 用している。インバータゲートの場合, 正常回路検查時に は $i_{\mathrm{DDT}}$ はほぼ 0 となるので, 式(3)の $I_{\mathrm{th}}$ は電流測定分解能で 決まる值で検査でき， $I_{\mathrm{th}}$ の設定が容易となる。インバー夕 ゲートでなくてもAND ゲートなど，他のゲートでも正常時 に電源電流がほとんど流れないものであれば INV と同様に オープンセンサとして使用できる。

本検查法による検査ではリード浮きが発生しない場合, IC\#i-1 からの出力である $\mathrm{H}$ もくは L Lベル信号が検查プ ローブを接触させたリードに伝えられ，INV の入力に伝わ 
る。リード浮きが発生した場合は IC\#i-1からの出力論理 值が INV に伝わらず INV の入力電圧は $v_{\mathrm{T}}$ で変化する。本検 查法はその現象を利用して検査するので, リード浮き検出 をするための検查プローブを接触させたリードへの出力は 八イインピーダンス出力以外であれば，つまり $\mathrm{H}$ しくは Lレベル信号であればどちらでもよいため, 検查入力生成 が非常に容易となる。

\section{3. 実験によるリード浮き検査能力評価}

本論文で提案する検查法のリード浮き検查能力を調 べるため, Fig. 2 の検査回路を試作し, Fig. 4 と Fig. 5 に示 す CUT\#1 \#3の 3 種類の回路におけるリード浮き検出 実験を行った。CUT\#1はFig. 4 に示すSOPタイプの SSI TC74HC00AFを使用した回路で, 本実験ではリード b リード浮き検出を試みた。CUT\#2およびCUT\#3 は Fig. 5 の 4 ビット加算器回路をプログラムしたCPLD LSIを用いた 回路で, CUT\#2では電源電圧5V の CPLD EPM7128 SQC10015 を, CUT\#3では電源電圧 $3.3 \mathrm{~V}$ の CPLD EPM7064AETC10010 を使用し、リード $\mathrm{e}$ のリード浮き検出を試みた。

試作した検查回路では INV として TC74HC04AP, $D_{1}$ とし て $1 \mathrm{~S} 1588$ を使用し， $R_{\mathrm{T}}$ は $1 \mathrm{k} \Omega$ とした。使用 INVの

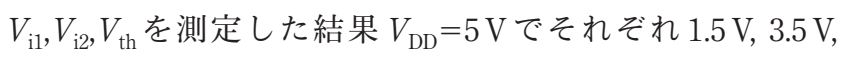
$2.5 \mathrm{~V}, V_{\mathrm{DD}}=3.3 \mathrm{~V}$ でそれぞれ $0.9 \mathrm{~V}, 2.4 \mathrm{~V}, 1.65 \mathrm{~V}$ であった。

本実験では DC $100 \mathrm{MHz}$ まで測定可能な Tektronix 製電 流プローブTCP312を使用し, ディジタルオシロスコープ TDS2024Bでサンプリング周波数 $2 \mathrm{GHz}$ で $i_{\mathrm{DDT}}$ を測定した。 検査プローブとしてはFig. 6(a) に示すミコジック社製プロー ビングスタンドPA-320を使用した。その検査プローブは Fig. 6(b)に示すように検査対象リードの上面に接触圧が $0.56 \mathrm{~N}$ で接触させた。

Fig. 4 で $V_{\mathrm{DD} 0}=5 \mathrm{~V}$ で $V_{\mathrm{TS}}=5 \mathrm{~V}, f_{\mathrm{T}}=1 \mathrm{kHz}$ 時の実験結果例を Fig. 7 と Fig. 8 に示す。CUT\#1 の正常時には ICHi-1の端子 aよりLレベルが出力されるため, $V_{\mathrm{TS}}=5 \mathrm{~V} の v_{\mathrm{T}}$ を印加し ても $v_{\mathrm{INV}}$ は $V_{\mathrm{i} 1}$ 以下となり， $i_{\mathrm{DDT}}$ はほとんど流れない。それ に対し，そのリードにリード浮きが発生した場合, Fig. 8 に示すように $10 \mathrm{~mA}$ より大きな $i_{\mathrm{DDT}}$ が流れ, 本検查法で検 出できることがわかる。また Fig. 8(a), (b)では Fig. 3 と同様 な波形が得られており， $V_{\mathrm{TS}} に よ っ て i_{\mathrm{DDT}}$ の波形が異なる ことがわかる。CUT\#1の場合 $V_{\mathrm{TS}}=3.0 \mathrm{~V}$ では 1 周期内に 2 度， $i_{\mathrm{DDT}}$ に異常が現れ，2.6Vではその異常が 1 度になり， さらに小さくなるとその異常が小さくなることがわかる。

われわれの実験では電源電圧 $5 \mathrm{~V}$ の CPLDを用いた CUT\#2でも Fig. 7 およびFig. 8 と同様な波形が得られた。そ れに対し電源電圧 $3.3 \mathrm{~V}$ の CPLDを用いたCUT\#3の場合, Fig. 9 に示すように, 正常時には $V_{\mathrm{TS}}=3.3 \mathrm{~V}$ の $v_{\mathrm{T}}$ を印加し ても $i_{\mathrm{DDT}}$ はほとんど流れない。それに対し，Fig. 10 に示す ようにリード浮き発生時には $i_{\mathrm{DDT}}$ に異常が現れるので, こ のリード浮きが検出できることがわかる。Fig. 8 と Fig. 10

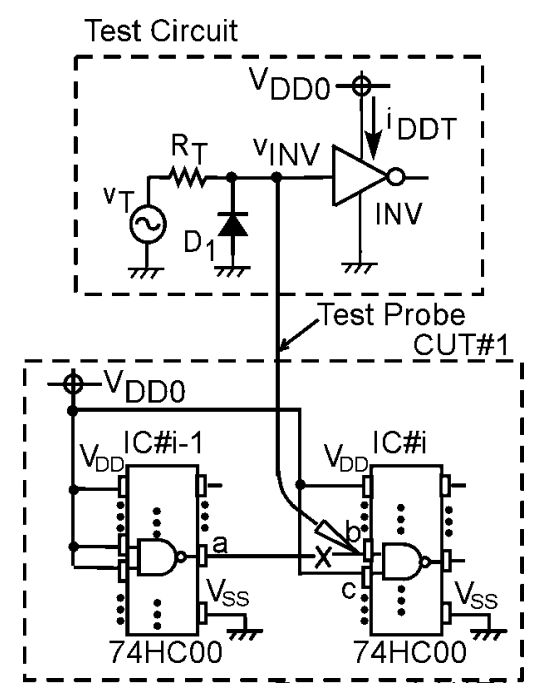

Fig. 4 Experimental circuit for CUT\#1

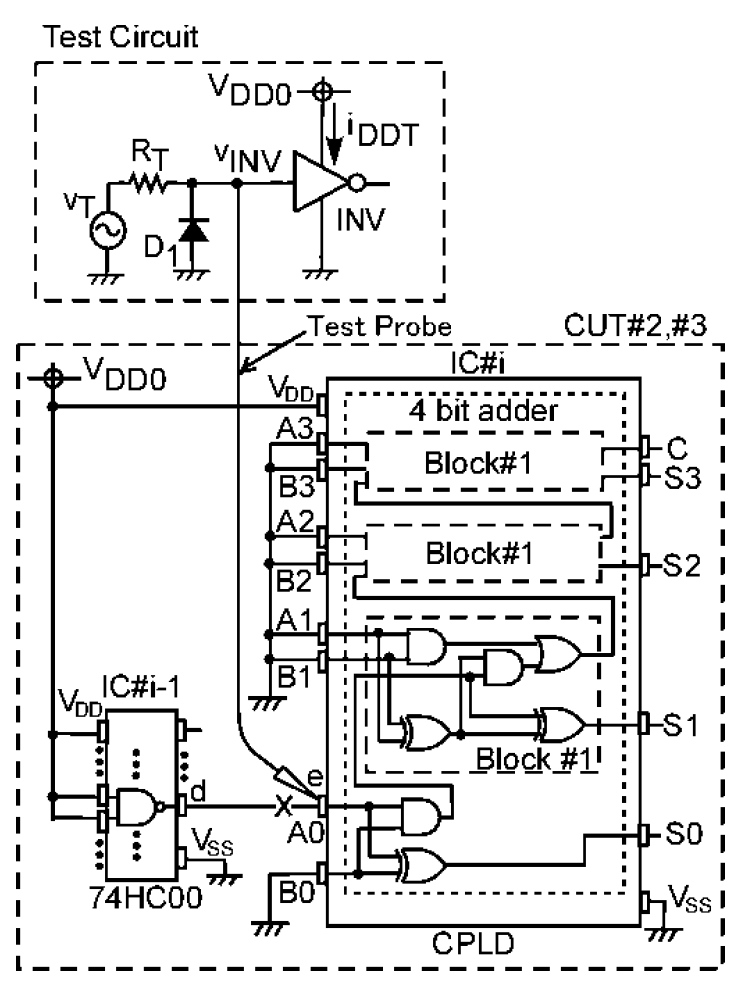

Fig. 5 Experimental circuit for CUT\#2 and \#3

を比較すると検查対象 IC の電源電圧が低くなると故障発生 時に $i_{\mathrm{DDT}}$ に現れる異常が小さくなることがわかる。 $V_{\mathrm{TS}}$ を 大きくしても Fig. 10(b) に示すように最大でも $7 \mathrm{~mA}$ の異常 しか $i_{\mathrm{DDT}}$ に現れない。しかし Fig. 9 の $i_{\mathrm{DDT}}$ 波形では現れな い大きな $i_{\mathrm{DDT}}$ が流れるので電源電圧 $5 \mathrm{~V}$ の SSI, CPLD LSI と 同様に $3.3 \mathrm{~V}$ 電源電圧の CPLD LSI のリード浮きも本検查法 で検出できることがわかる。

リード浮き発生時の $v_{\mathrm{INV}}$ の変化速度は $v_{\mathrm{T}}$ の $f_{\mathrm{T}}$ に依存する ため, $f_{\mathrm{T}}$ が大きくなると， $v_{\mathrm{INV}}$ が大きくなる前に $v_{\mathrm{T}}$ が小さ くなり $i_{\mathrm{DDT}}$ に現れる異常が小さくなる。たとえばCUT\#1の リード浮き発生時に $f_{\mathrm{T}}=1 \mathrm{MHz}$ の $v_{\mathrm{T}}$ 印加時に得られる波形 を Fig. 11(a)に示す。Fig. 8(a) と Fig. 11(a)の比較から， $f_{\mathrm{T}}$ を 


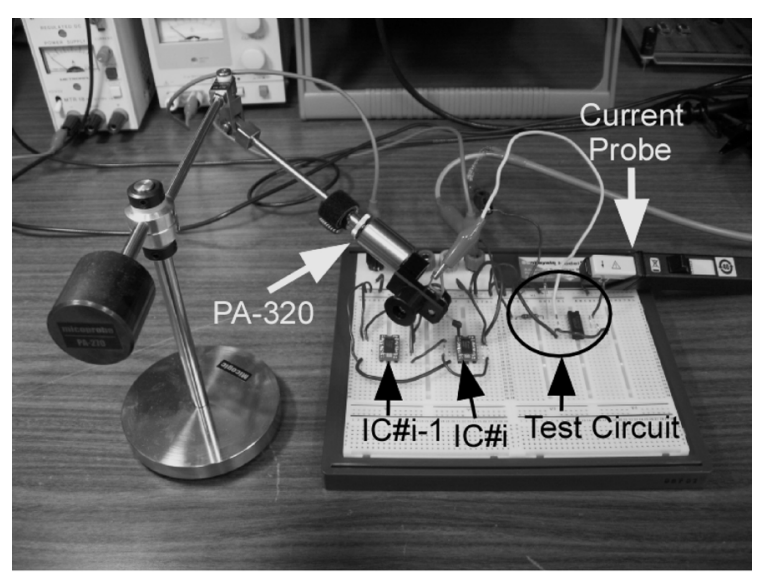

(a) Instruments and apparatuses used in our experiments

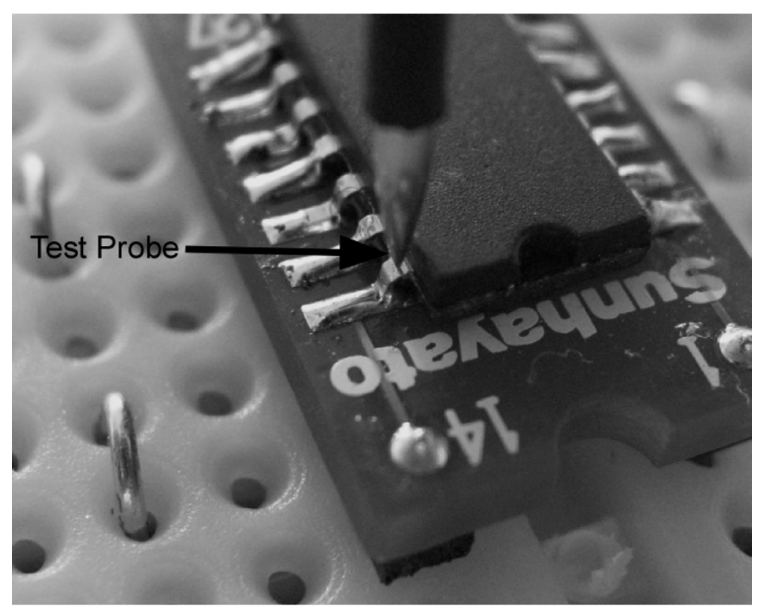

(b) Test probe attachment

Fig. 6 Attachment of test probe to targeted lead

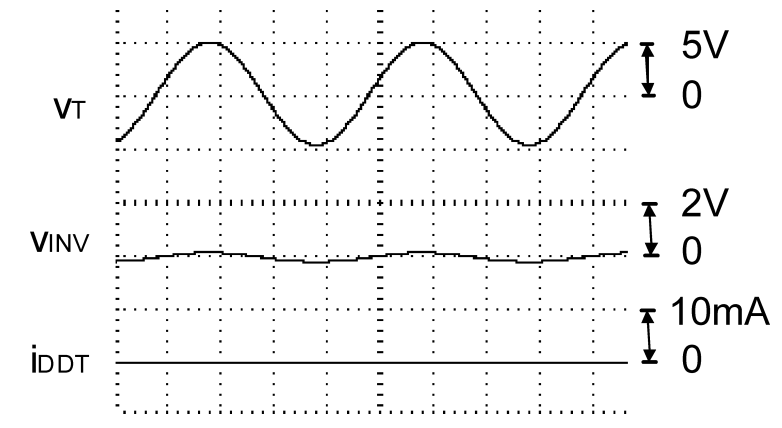

Fig. $7 \quad i_{\mathrm{DDT}}$ of defect-free CUT\# $1 \quad\left(V_{\mathrm{DD} 0}=V_{\mathrm{TS}}=5 \mathrm{~V}, f_{\mathrm{T}}=\right.$ $1 \mathrm{kHz}$ )

大きくすると $i_{\mathrm{DDT}}$ に現れる異常が小さくなることがわかる。 しかし $V_{\mathrm{TS}}$ を大きくすると $v_{\mathrm{INV}}$ は短時間に大きくなるので $i_{\text {DDT }}$ 異常を大きくすることができる。たとえばFig. 11(a) と 同じ $f_{\mathrm{T}}$ で $V_{\mathrm{TS}}$ を $2.6 \mathrm{~V}$ から $3 \mathrm{~V}$ に大きくした場合の測定結果 を Fig. 11(b) に示す。Fig. 11(a) と Fig. 11(b)より， $V_{\mathrm{TS}}$ を大き くすることでも, 現れる $i_{\mathrm{DDT}}$ 異常を大きくできることがわ かる。

このように $i_{\mathrm{DDT}}$ に現れる異常は $V_{\mathrm{TS}}$ と $f_{\mathrm{T}}$ で変化すること から,さまざまな $V_{\mathrm{TS}}$ と $f_{\mathrm{T}}$ の $v_{\mathrm{T}}$ を印加し, 測定した $i_{\mathrm{DDT}}$ 波

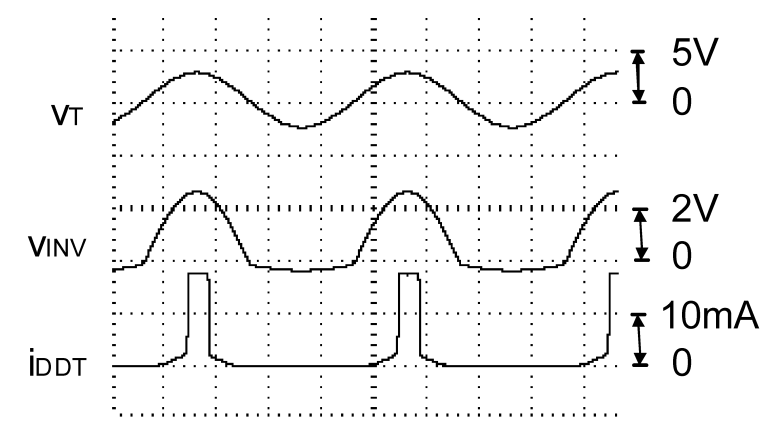

(a) $\mathrm{V}_{\mathrm{TS}}=2.6 \mathrm{~V}$

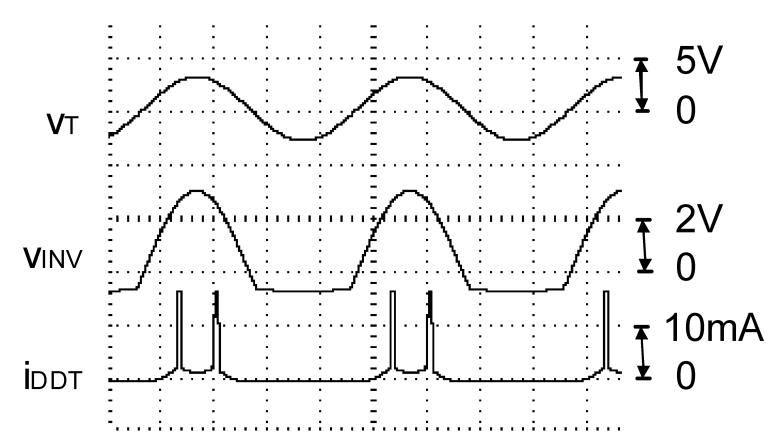

(b) $\mathrm{V}_{\mathrm{TS}}=3.0 \mathrm{~V}$

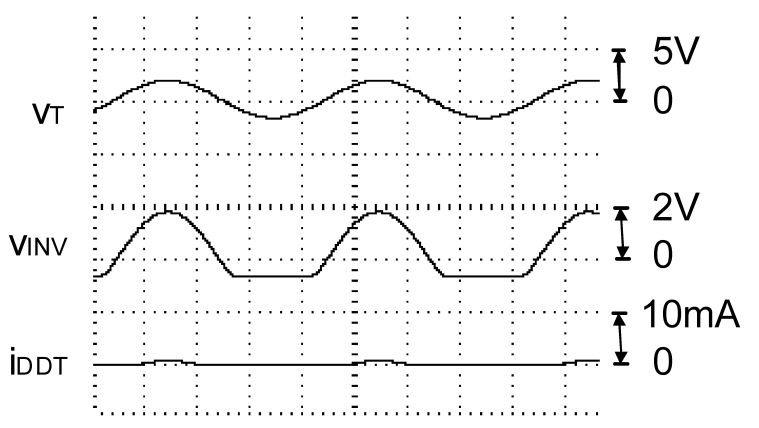

(c) $\mathrm{V}_{\mathrm{TS}}=2.0 \mathrm{~V}$

Fig. $8 i_{\mathrm{DDT}}$ of CUT\#1 having open lead $\left(V_{\mathrm{DD} 0}=5 \mathrm{~V}, f_{\mathrm{T}}=\right.$ $1 \mathrm{kHz})$

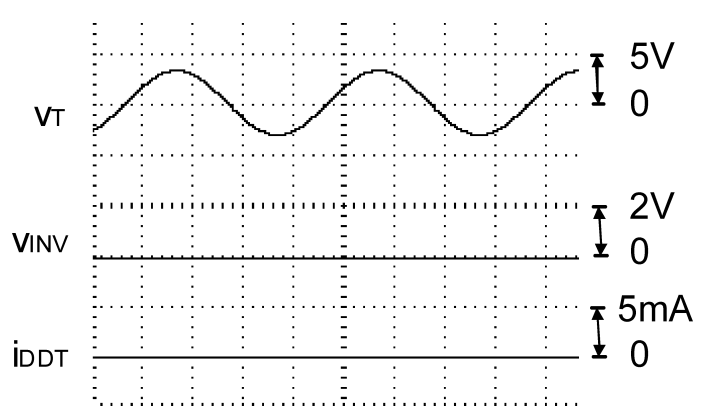

Fig. $9 i_{\mathrm{DDT}}$ of defect-free CUT\#3 $\left(V_{\mathrm{DD} 0}=V_{\mathrm{TS}}=3.3 \mathrm{~V}, f_{\mathrm{T}}=1\right.$ $\mathrm{kHz}$ )

形のピーク值の平均值 $I_{\mathrm{DDTp}}$ を導出してみた。その結果を Table 1 3に示す。これらの表で( ) で囲んだ $I_{\mathrm{DDTp}}$ の $V_{\mathrm{TS}}, f_{\mathrm{T}}$ では $i_{\mathrm{DDT}}$ に現れる異常值が $I_{\mathrm{th}}$ より小さく, 本検査法で検出 できないことを表している。ここで $I_{\text {th }}$ は Table 1, Table 2 で は $0.8 \mathrm{~mA}$, Table 3 では $0.4 \mathrm{~mA}$ としている。それは Table 1, 


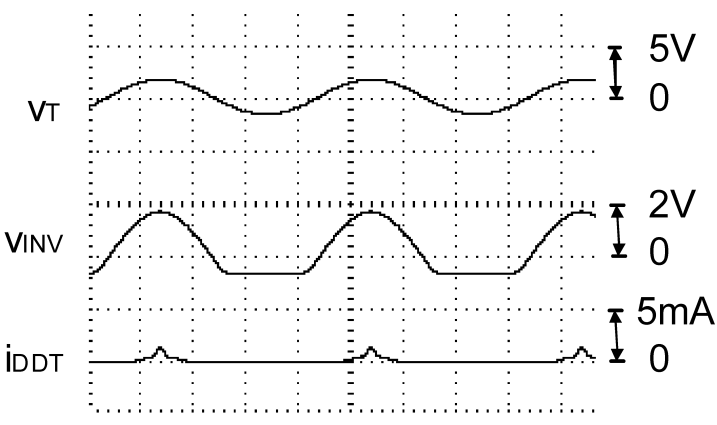

(a) $\mathrm{V}_{\mathrm{TS}}=1.7 \mathrm{~V}$

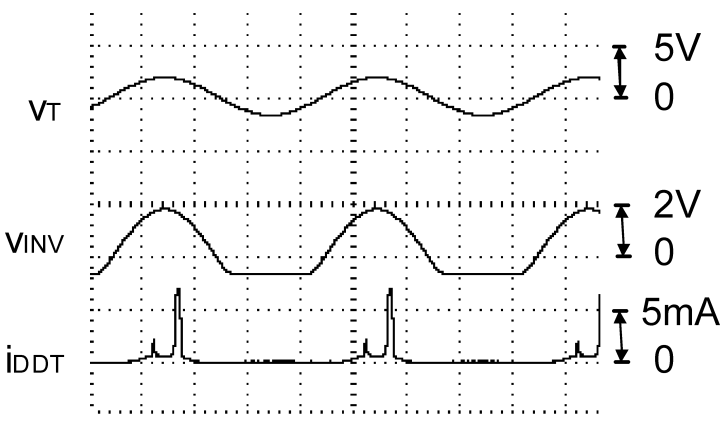

(b) $\mathrm{V}_{\mathrm{TS}}=1.8 \mathrm{~V}$

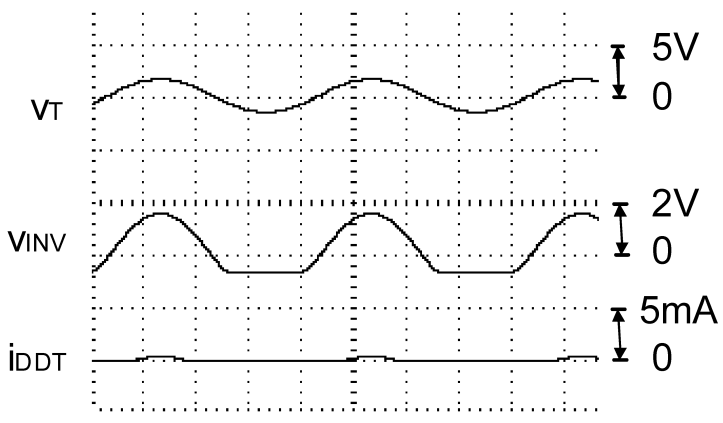

(c) $\mathrm{V}_{\mathrm{TS}}=1.5 \mathrm{~V}$

Fig. $10 i_{\mathrm{DDT}}$ of CUT\#3 having open lead $\left(V_{\mathrm{DD} 0}=3.3 \mathrm{~V}, f_{\mathrm{T}}=\right.$ $1 \mathrm{kHz}$ )

Table 2 の実験では $0.4 \mathrm{~mA} /$ div, Table 3 の実験では $0.2 \mathrm{~mA} / \mathrm{div}$ の分解能で測定したので, その $\mathrm{A} / \mathrm{D}$ 変換䛊差による䛊判定 を防止するため測定分解能の 2 倍の值を $I_{\mathrm{th}}$ としたためであ る。

電源電圧 5 V IC を用いた回路の実験結果である Table 1 で は $1.8 \mathrm{~V}$ 以上の $V_{\mathrm{TS}}$, Table 2 では $1.9 \mathrm{~V}$ 以上の $V_{\mathrm{TS}}$, 電源電圧 $3.3 \mathrm{~V} \mathrm{IC}$ を用いた回路の実験結果である Table 3 では $1.6 \mathrm{~V}$ 以 上の $V_{\mathrm{TS}}$ であれば, $1 \mathrm{MHz}$ の $v_{\mathrm{T}}$ 印加でリード浮きが検出で きることがわかる。なお Table $1 \sim 3$ で $f_{\mathrm{T}}=500 \mathrm{kHz}$ の時が もっとも $i_{\mathrm{DDT}}$ のピーク值の平均值が大きくなっている。そ れは $i_{\mathrm{DDT}}$ 変化が Fig. 8 (b), Fig. 10 (b)に示すように短期間に 発生し，たまたま $f_{\mathrm{T}}=500 \mathrm{kHz}$ の場合に短期間に発生する $i_{\mathrm{DDT}}$ 異常をサンプリングできる頻度が多かったためである。

実用的にはリード浮き発生時に現れる $i_{\mathrm{DDT}}$ 異常はできる だけ大きい方が確実にリード浮きが発見できるため好まし い。そこで, 最大に近い $i_{\mathrm{DDT}}$ 異常を発生できる $V_{\mathrm{TS}}$ と $f_{\mathrm{T}}$ を

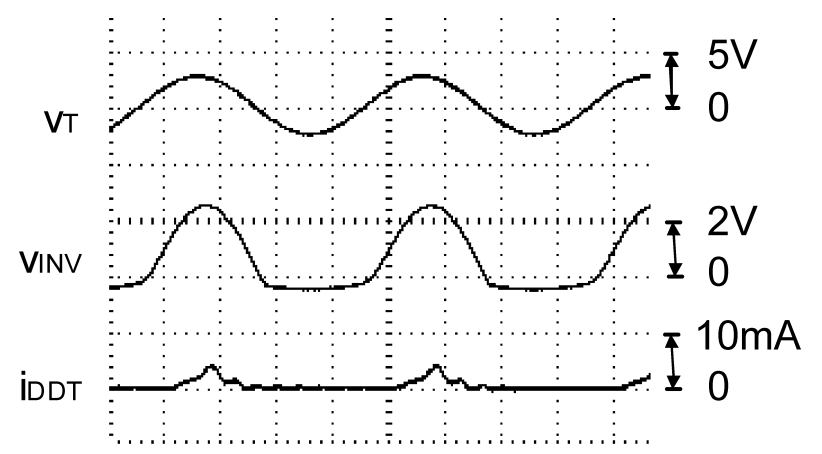

(a) $\mathrm{V}_{\mathrm{TS}}=2.6 \mathrm{~V}$

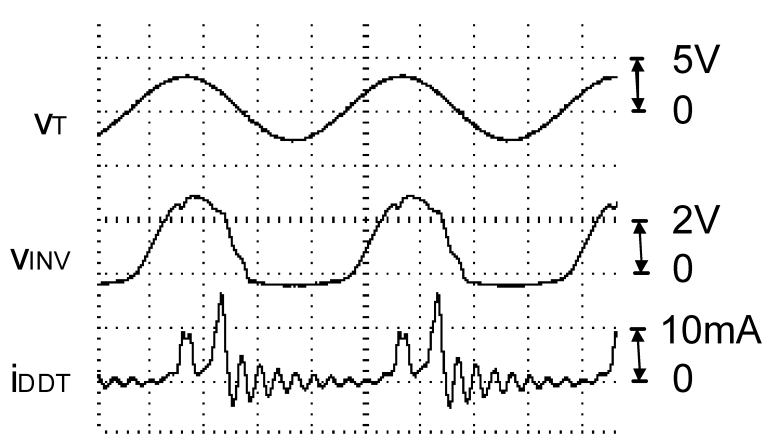

(b) $\mathrm{V}_{\mathrm{TS}}=3.0 \mathrm{~V}$

Fig. $11 i_{\mathrm{DDT}}$ of CUT\#1 generated by $v_{\mathrm{T}}$ of high frequency

Table 1. $I_{\mathrm{DDTp}}$ in CUT\#1 having open lead [mA]

\begin{tabular}{r|r|r|r|r|r|r|r|r|r|r}
\hline \multirow{2}{*}{$\begin{array}{c}f_{\mathrm{T}} \\
{[\mathrm{kHz}]}\end{array}$} & \multicolumn{10}{|c}{$V_{\mathrm{TS}}[\mathrm{V}]$} \\
\cline { 2 - 11 } & 5.0 & 4.5 & 4.0 & 3.5 & 3.0 & 2.5 & 2.0 & 1.9 & 1.8 & 1.7 \\
\hline 1 & 17.2 & 16.8 & 17.2 & 16.8 & 16.4 & 6.0 & 1.2 & 1.2 & 0.8 & $(0.4)$ \\
\hline 2 & 16.8 & 16.4 & 16.8 & 16.4 & 16.4 & 2.8 & 0.8 & 0.8 & 0.8 & $(0.4)$ \\
\hline 5 & 16.8 & 16.4 & 16.8 & 16.4 & 16.0 & 2.8 & 1.2 & 0.8 & 0.8 & $(0.4)$ \\
\hline 10 & 16.4 & 16.0 & 16.8 & 16.0 & 16.4 & 2.8 & 1.2 & 0.8 & 0.8 & $(0.4)$ \\
\hline 20 & 16.4 & 16.0 & 16.4 & 16.0 & 16.0 & 2.8 & 1.2 & 0.8 & 0.8 & $(0.4)$ \\
\hline 50 & 16.8 & 16.0 & 16.8 & 16.0 & 16.0 & 2.8 & 1.2 & 0.8 & 0.8 & $(0.4)$ \\
\hline 100 & 16.8 & 16.0 & 16.8 & 16.0 & 16.0 & 2.8 & 1.2 & 0.8 & 0.8 & $(0.4)$ \\
\hline 200 & 16.8 & 16.4 & 17.2 & 16.4 & 16.4 & 2.8 & 1.2 & 1.2 & 0.8 & $(0.4)$ \\
\hline 500 & 15.6 & 16.0 & 16.8 & 16.8 & 16.8 & 3.2 & 1.6 & 1.6 & 1.2 & 1.2 \\
\hline 1000 & 11.2 & 11.6 & 13.2 & 14.4 & 15.6 & 2.4 & 1.2 & 1.2 & 0.8 & 0.8 \\
\hline
\end{tabular}

それらの表から求めてみると, Table 1 , Table 2 では $V_{\mathrm{TS}}$ が $3.0 \mathrm{~V}$ 以上であれば $1 \mathrm{MHz}$ まで $10 \mathrm{~mA}$ 以上の $i_{\mathrm{DDT}}$ 異常を発生 できている。Table 3 では $V_{\mathrm{TS}}$ が $1.8 \mathrm{~V}$ 以上なら $1 \mathrm{MHz}$ まで $3 \mathrm{~mA}$ 以上の $i_{\mathrm{DDT}}$ 異常を発生できている。これらのことは検 査対象回路の電源電圧の 0.6 倍の $V_{\mathrm{TS}}$ で $f_{\mathrm{T}}$ が $1 \mathrm{MHz}$ の $v_{\mathrm{T}}$ を 印加することで本検査法でリード浮きが確実に検出できる ことを表している。また本検査法では $1 \mathrm{MHz}$ の $v_{\mathrm{T}}$ でリード 浮きを発見でき, また 1 周期分の $v_{\mathrm{T}}$ 印加でリード浮きを検 出できることから，検査対象リードに検査プローブを接触

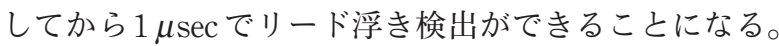


Table 2. $I_{\mathrm{DDTp}}$ in CUT\#2 having open lead $[\mathrm{mA}]$

\begin{tabular}{r|r|r|r|r|r|r|r|r|r|r}
\hline \multirow{2}{*}{$\begin{array}{c}f_{\mathrm{T}} \\
{[\mathrm{kHz}]}\end{array}$} & \multicolumn{10}{|c}{$V_{\mathrm{TS}}[\mathrm{V}]$} \\
\cline { 2 - 11 } & 5.0 & 4.5 & 4.0 & 3.5 & 3.0 & 2.5 & 2.0 & 1.9 & 1.8 & 1.7 \\
\hline 1 & 16.4 & 16.4 & 16.4 & 16.4 & 16.4 & 4.0 & 1.2 & 0.8 & 0.8 & $(0.4)$ \\
\hline 2 & 16.0 & 16.0 & 16.0 & 16.4 & 16.0 & 3.6 & 1.2 & 0.8 & $(0.4)$ & $(0.0)$ \\
\hline 5 & 15.6 & 16.0 & 16.0 & 16.4 & 16.0 & 4.0 & 1.2 & 0.8 & $(0.4)$ & $(0.4)$ \\
\hline 10 & 15.2 & 15.6 & 15.6 & 16.4 & 16.0 & 4.0 & 1.2 & 0.8 & $(0.4)$ & $(0.0)$ \\
\hline 20 & 15.2 & 15.2 & 16.0 & 16.0 & 16.0 & 4.0 & 1.2 & 0.8 & $(0.4)$ & $(0.0)$ \\
\hline 50 & 15.6 & 15.6 & 16.0 & 16.0 & 15.6 & 3.6 & 1.2 & 0.8 & $(0.4)$ & $(0.0)$ \\
\hline 100 & 15.6 & 15.2 & 16.0 & 16.0 & 15.6 & 3.6 & 1.2 & 0.8 & $(0.4)$ & $(0.0)$ \\
\hline 200 & 15.6 & 16.0 & 16.4 & 16.4 & 16.0 & 3.6 & 1.2 & 0.8 & $(0.4)$ & $(0.4)$ \\
\hline 500 & 17.2 & 17.2 & 18.0 & 18.0 & 17.2 & 3.6 & 1.6 & 1.2 & 0.8 & 0.8 \\
\hline 1000 & 12.0 & 13.6 & 16.4 & 17.6 & 17.2 & 2.8 & 1.2 & 0.8 & $(0.4)$ & $(0.4)$ \\
\hline
\end{tabular}

Table 3. $I_{\mathrm{DDTp}}$ in CUT\# 3 having open lead $[\mathrm{mA}]$

\begin{tabular}{r|c|c|c|c|c|c|c|c}
\hline \multirow{2}{*}{$\begin{array}{c}f_{\mathrm{T}} \\
{[\mathrm{kHz}]}\end{array}$} & \multicolumn{7}{|c}{$V_{\mathrm{TS}}[\mathrm{V}]$} \\
\cline { 2 - 9 } & 3.3 & 3.0 & 2.5 & 2.0 & 1.8 & 1.6 & 1.5 & 1.4 \\
\hline 1 & 6.6 & 6.6 & 6.8 & 6.6 & 7.0 & 0.4 & 0.4 & $(0.2)$ \\
\hline 2 & 6.2 & 6.2 & 6.4 & 6.4 & 6.8 & 0.4 & $(0.2)$ & $(0.2)$ \\
\hline 5 & 6.0 & 6.0 & 6.4 & 6.2 & 6.6 & 0.4 & $(0.2)$ & $(0.2)$ \\
\hline 10 & 6.0 & 5.6 & 6.2 & 6.0 & 6.6 & 0.4 & $(0.2)$ & $(0.2)$ \\
\hline 20 & 5.8 & 5.4 & 5.8 & 5.8 & 6.4 & 0.4 & $(0.2)$ & $(0.2)$ \\
\hline 50 & 5.6 & 5.6 & 5.8 & 5.8 & 5.8 & 0.4 & $(0.2)$ & $(0.2)$ \\
\hline 100 & 4.2 & 4.2 & 4.8 & 5.4 & 5.8 & 0.4 & $(0.2)$ & $(0.2)$ \\
\hline 200 & 4.2 & 4.2 & 4.0 & 4.0 & 5.8 & 0.4 & $(0.2)$ & $(0.2)$ \\
\hline 500 & 5.0 & 5.0 & 4.8 & 4.2 & 5.4 & 0.6 & 0.4 & 0.4 \\
\hline 1000 & 3.6 & 3.6 & 3.4 & 4.0 & 5.0 & 0.4 & $(0.2)$ & $(0.2$ \\
\hline
\end{tabular}

現実には検査プローブを検査対象リードに接触させる時

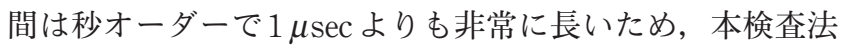
の実質的な検查速度は検査プローブを検査対象リードに接 触させるのに必要な時間で決まることになる。

\section{4. 結 言}

検査対象リードに検査プローブを接触させ交流電圧を印 加し，オープンセンサとして使用する CMOS ゲート IC の電 源電流異常でリードに発生する断線故障を検出する検査法 とその検査回路を提案し, その検査能力を実験により評価 した。その結果, 検査対象 IC の電源電圧の 0.6 倍の振幅で 周波数 $1 \mathrm{MHz}$ の交流電圧信号を検査対象リードに印加する ことにより, リードに発生する断線故障が本検査法で検出 できることがわかった。
本検査法は，検査回路が単純なものですみ，検査入力生 成も容易となることから，実用性の高い検査法である。同 時に複数個のリードの検査を可能にする検査回路の開発に よりこの検査法の実用性はさらに高まるので，その検査回 路の開発が今後の課題として残っている。

\section{謝辞}

本研究の一部は電子回路基板技術振興財団の助成金(No. 191A05), および日本学術振興会の科学研究補助金（基盤 研究(C), No. 18500039）によるものである。ここに謝意を 表します。

(2008.6.27-受理)

\section{文献}

1) H. Bleeker, P. van den Eijnden and F. de Jong: "Boundary-Scan Test: A Practical Approach”, Kluwer Academic Publishers, 1993

2) 原 靖彦：“検査技術の動向－外観検查”，エレクトロニク 又実装学会誌，Vol. 2, No. 4, pp. 264-268, 1999

3）検査技術委員会：“X線検査装置の現状と展望”，エレクト ロニクス実装学会誌, Vol. 7, No. 1, pp. 24-26, 2004

4) 小路祐吉，高津直由，王 征成：“ニューラルネットによ るはんだ外観検査”，電子情報通信学会論文誌，Vol. J78D-II, No. 4, pp. 589-596, 1995

5）岡部健二，金田 一：“レーザ式変位計によるプリント基 板の IC 実装検査”，計測自動制御学会論文集，Vol. 34, No. 9, pp. 1127-1132, 1998

6) 小林 正：“検查技術の動向－電気検査”，エレクトロニク ス実装学会誌，Vol. 2, No. 4, pp. 259-263, 1999

7) M. Sc. Mahnaz Salamati: "Electromagnetic Signatures as a Tool for Connectionless Test (CT)", IEEE Board Test Workshop 2002,http://www.molesystems.com/BTW/material/ BTW02//btw02-3-2.pdf

8）久我宣裕，大西健一，土井 充，遠藤充哲：“相互変調ひ ずみを用いた電気接続不良の非接触検出”，第 21 回エレク トロニクス実装講演大会論文集，16 A-05, 2007

9) 一宮正博, 橋爪正樹, 四柳浩之, 為貞建臣：“CMOS論理 IC の交流電界印加時の電源電流測定によるリード浮き検出 法”，エレクトロニクス実装学会誌，Vol. 6, No. 2, pp. 140146,2003

10) A. Ono, M. Hashizume, M. Ichimiya and H. Yotsuyanagi: "Open Lead Detection of CMOS ICs by Low Pressure Probing", Proc. of ICEP07, pp. 359-364, 2007

11) 高木正夫，橋爪正樹，一宮正博，四柳浩之：“交流電界印 加時の電流テストによるCMOS LSI のリード浮き検出のた めの印加交流電压”，エレクトロニクス実装学会誌，Vol. 10, No. 3, pp. 219-228, 2007 